\title{
Conservation of irregular stone masonry in Tanais in Russia
}

\author{
Wojciech Terlikowski ${ }^{1^{*}}$, Marcin Matera ${ }^{2}$, Kacper Wasilewski ${ }^{1}$, Martyna Gregoriou- \\ Szczepaniak $^{1}$, Ewa Sobczyńska ${ }^{1}$ \\ ${ }^{1}$ Warsaw University of Technology, 16 Lecha Kaczyńskiego Str., 00-637 Warsaw, Poland \\ ${ }^{2}$ Institute of Archaeology, University of Warsaw, 26/28 Krakowskie Przedmieście, 00-927 Warsaw, \\ Poland
}

\begin{abstract}
The article presents and describes the conservation of masonry structures at archaeological site in Tanais near Rostov-on-Don in Russia. The authors' experiences presented in the article result from many years of cooperation between the Faculty of Civil Engineering at the Warsaw University of Technology and the Centre for Research on the Antiquity of Southeastern Europe at the University of Warsaw. Works on masonry structures located in the area of archaeological excavations are characterized by a unique specificity covering both formal issues, resulting from international standards and agreements regulating the conservation of historic buildings, as well as technical and environmental issues. The basic technical issues include ensuring the safety of further excavation works, protection of masonry structures against the destructive effects of atmospheric condition and preparing the structure for possible presentation in archaeological parks organized on the site of trenches. Environmental issues relate to local, social and economic conditions. The article presents the procedures that should be used in the maintenance of antique irregular masonry and presents the specific technological and material solutions used in the example objects.
\end{abstract}

\section{Introduction}

The ancient town of Tanais was formerly located probably at the shore of Azov Sea and at the same time at the mouth of the Don River [1,2]. Nowadays, due to hydrological changes of this area [3,4], it is located on the right bank of the Mertvy Donets.

Tanais was founded at the end of 60's/at the beginning of 50's of the 3rd century BC [5] by Greek settlers and existed until the middle of the 3rd century AD, when it was totally destroyed. During its history Tanais was destroyed twice more - at the very end of 1st century BC by Bosporanean King Polemon and in the middle of 2 nd century AD. In the second half of the 4th century and in the first half of the 5th century, the territory of Tanais was again inhabited and then finally abandoned. The chronology was studied by Arsen'eva et al. [6].

Works of Polish archaeologists at this site have been carried out there since 1995 by two institutions of the University of Warsaw - former Archaeological Research Centre of

\footnotetext{
* Corresponding author: w.terlikowski@il.pw.edu.pl
} 
Novae (present Antiquity of Southern Eastern Europe Research Centre) and the Institute of Archaeology. Since 1999, Polish research has been carried out in trench XXV located in the western part of Western Tanais. The initial purpose of the work was to verify route and construction of a western line of fortifications. So far remains of a defensive system such as ditch, stone-wooden bridge leading to the town's gate and two curtains of walls were discovered. A part of residential housing inside the town's walls and the fragment of an urban street grid were also unearthed. So far there were six rooms fully or partially explored. The results of archaeological excavation in trench XXV were scope of works of Scholl [7-19] and Matera [20-21].

The street 'a' (Fig. 1) ran eastward from the gate to the so-called citadel of Tanais. The street ' $b$ ' had a strategic importance and ran parallel to the curtains of defensive walls. To the north of street ' $a$ ' an architectural complex of rooms ' $A$ ' and ' $D$ ' was located. To the south of this street another complex of several rooms ('B', ' $C$ ', ' $E$ ' and ' $F$ ') was situated.

All of discovered architectural remains are dated to Hellenistic period. However in the rooms ' $\mathrm{C}$ ' and ' $\mathrm{F}$ ' and to the south of them the traces of reconstruction performed already in the 1 st century AD were recorded [22].

Heretofore, conservation works at Tanais site carried by authors consist of two seasons in years $2016-2017$. The research was carried out as part of conservation missions by the Division of Fundamental of Building and Sustainable Development of the Civil Engineering Faculty of the Warsaw University of Technology in cooperation with the Institute of Archaeology of the University of Warsaw and the Antiquity in South-eastern Europe Research Centre . The first season was oriented on detailed documentation with a 3$\mathrm{d}$ scanner [23]. One of the outcomes of that documentation is three-dimensional model of the trench XXV, which allows to perform precise measurements of structures located inside (Fig. 1).

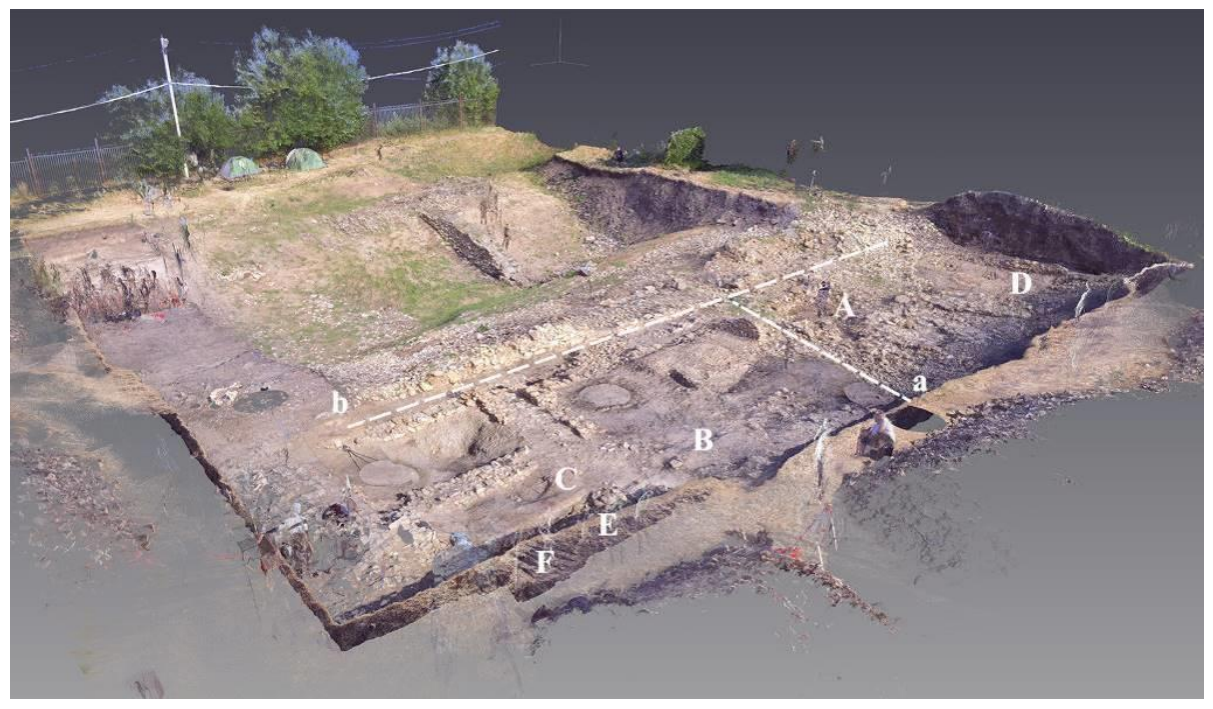

Fig. 1. Three-dimensional model of trench XXV in Tanais, Russia (explanation of symbols in text).

Conservation work carried out in 2017 season was focused on the room ' $D$ ' located in the north-east corner of the trench (Fig. 1). A partial reconstruction was performer with semi-anastylosis method using clay mortar stabilised with lime and cement. Due to the trial stage of conservation work, the pointing with clay mortar, which is a stage of the conservation procedure described in the previous parts, was not applied. Results of the conservation work is presented in the Fig. 2. For the following season it is planned to verify 
and evaluate the work from the previous season. If it is necessary, the conservation assumptions will be modified for upcoming applications in this excavation.
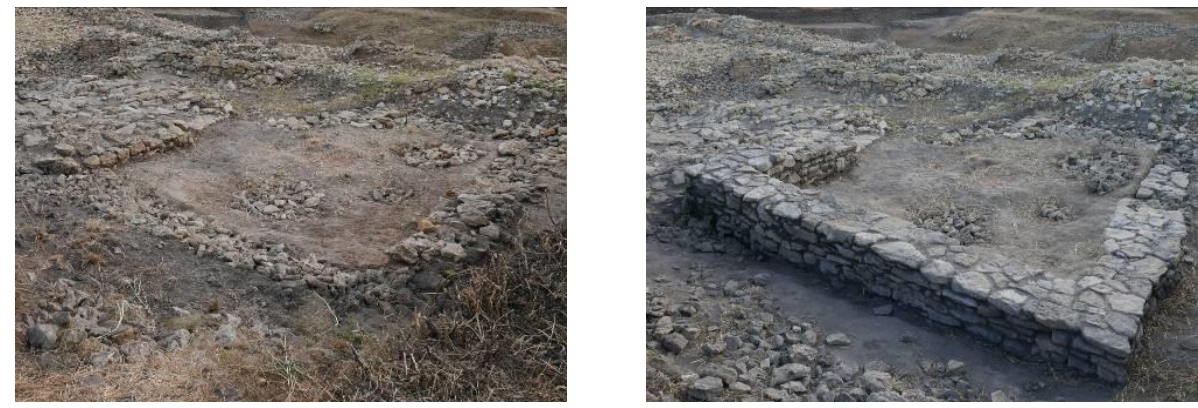

Fig. 2. Walls of the room 'D' located in the north-eastern part of trench XXV before (on the left) and after (on the right) conservation works in 2017.

\section{Material and technical identification of historic masonry structures}

Correct diagnosis of historic masonry structures constitutes the basis for the effectiveness of all other activities related to their maintenance, strengthening, rehabilitation and preparation for their later exposure. Detailed identification of materials, technology and techniques for the construction of historic building, as well as a proper understanding of load bearing structure and the work resulting from real static scheme should be a part of this diagnostic. Building materials, as well as the techniques and technologies used in construction today are, in principle, well known. In the case of ancient buildings, we often deal with techniques and technologies not used today, and often archaeological discoveries show techniques that today are completely unknown or known only locally.

Masonry elements forming historic masonry structures often differ in their material properties (stones of different mineral composition, derived from different rocks, dried bricks, ceramic bricks, etc.), physical properties (gravity, density, tightness, porosity, weight and volume absorbability, rate of saturation, thermal conductivity, thermal capacity, freezing resistance, fire resistant) and mechanical properties (strength, hardness, abrasion and impact-resistant), as well as in overall dimensions and shapes (large and small elements, sortable and non-sortable stones, rectangular or with complicated shape elements).

Identification of materials, masonry elements, kind of join between elements, their shapes, physical and mechanical parameters has multi-faceted significance for the monument that goes beyond the architectural, structural or conservative aspects. Proper identification of materials and technologies used is also important in terms of historical, cultural, aesthetic, environmental, social or even economic impact.

The conservation aspect shows the relationship of the originally used materials, techniques and technology with activities aimed at securing and preserving the monument, inhibiting its destruction, and documentation of these activities. These actions, as already mentioned, are conditioned by international arrangements and principles, including the principle of compatibility of materials, techniques and construction technologies.

The architectural aspect shows the impact of applied materials and technologies on form of the building, an architectural-functional system, canons, and styles of the particular historical period. The architectural aspect is closely related to the aesthetic one that results from the definitions of beauty of the given periods of time, but that always has the element of subjective assessment. 
The structural aspect of proper identification of the materials and technologies used in the construction of a particular historic building is of fundamental importance. The proper recognition of the construction technique used, the physical and mechanical properties of the materials used gives the possibility of proper assessment of the technical condition of an construction or its fragment, proper determination of load bearing structures work, including issues connected with structural rigidity of historical buildings. Knowledge of the physical and mechanical properties of the materials used for the construction of historic buildings gives the possibility of proper verification of structural strength, as well as the adoption of appropriate rehabilitation solution, security and reinforcement measures. Awareness of destructive processes occurring during the existence of the construction and changes in natural environment, create the need for conducting diagnostic tests also in the environmental aspect.

The historical aspect relates to proper material and technical diagnostics in the context of architecture and construction history, including the proper recognition of construction techniques and technologies closely related to the art of building applied in a given region, during a specific historical period. By comparing these techniques with others used in a particular area and beyond, we can draw conclusions about the development and evolution of the construction, as well as learn the principles that often constitute the basis of styles and architectural and construction trends. The historical aspect is closely related to the cultural one. Construction and architecture are always part of culture being a manifestation of a particular civilization. The findings concerning ancient monuments result from archaeological, architectural, construction and conservation studies and analyses. They are usually crucial for further conservation and rehabilitation works.

Proper material and technical identification of the historical walls should be the basis for further conservation and construction work, including protection and reinforcement. It gives an extensive knowledge about masonry elements, mortars or coupler, bond types and technology or technique used. Conservation works should be based on original materials, construction elements and technologies; this is of particular importance for the preservation of historical and cultural truth and the application of appropriate structural and technological solutions.

\section{Methodology of conservation of ancient masonry structures at archaeological excavations}

\subsection{Characteristics of irregular masonry}

One of the common types of ancient masonry structures exposed as part of archaeological excavations are irregular masonries. In case of sites where the research was carried out, they were made of ashlars and stones from various limestone rocks, shaped or broken, mostly unsorted, of different structure, degree of sedimentation, porosity and absorbability, and, what is associated with it, humidity. Some types of rocks from which masonry elements were made also shown granular disintegration. A clay mortar based on clay and sand found in the surrounding soil was used as the binder. Such a wall has low strength, internal cohesion and as a result - low durability. The structure of the walls is degraded to a large extent, which in addition to possible conscious human impact, results from centurieslong environmental processes, including long-term moisture and biological aggression in the ground and destruction caused by exposure to rainwater.

The specificity of the irregular masonries, their structural and physical properties make their conservation a complex and difficult process. In the case of structures located in Tanais in Russia, the additional problem was biological destruction, caused by the damaging effects of green plants, lichens and weeds growing in spring in the trench. 
Environmental impacts are characterized by high temperatures in the summer, with strong solar radiation and low temperatures in winter, with snowfall and negative temperatures causing freezing of water. There is also heavy rainfall in autumn and spring. These are the impacts that further complicate the conservation works and cause the destruction of the wild walls. The basic problems that need to be solved during conservation works are: reduction of absorption of water, increasing internal cohesion, related to the need to consolidate the internal wall structure, restoration and protection of damaged parts of walls, reprofiling with removal of destructive plant interactions.

\subsection{Maintenance works' program and assumptions}

Based on the authors experiences [24, 25] and conservation standards [26], the following conservation assumptions were adopted:

- Works conducted on stone structures have to be comprehensive and based on reliable researches with caution and due to rule of conservation and construction interference minimization as a preservation of natural and original nature of monuments.

- Stone structures' conservation should take into account its exceptional nature, historical, educational and aesthetic value. Monuments have to be prepared to public exposition in a permanent ruin state in its natural environment. All eventual substructures and complements should be recognizable and easily distinguished from original structures.

- Due to impossibility of total elimination of destructive environmental influence (season rains, moisture, low temperatures, frosting and defrosting process of water in masonry structures and units, weathering processes) it should be minimized and the most damaged and endangered structures should be consolidated.

- It is absolutely necessary to eliminate or limit the biological destruction of trench and masonry structures by permanent removal of plants and lichens.

- All reprofiling activities of the walls should be made after previous detailed survey of the original wall structure. Reprofiling of the wall and reconstruction of its part can take place only through anastylosis or semi-anastylosis (the use of wall elements, which we are sure that formed a wall, although we are not sure where exactly they originally were), preserving the original way of binding and arranging wall elements.

- Works undertaken for the first time in a given area, have to be considered as trial works, of which results should be examined in following years and used as a base to further improvement of applied treatment. Therefore, such works should not be carried out in a wide range and should not relate to the most important monuments from a given area.

- Conservation materials should be selected based on the conservation knowledge, rules and experience and in compliance with the principles of compatibility of materials but, moreover, it should include social aspects (for example possibility of theft or devastation), economical aspects and availability.

\subsection{Stages of conservation works}

On the basis of the conservation works it is possible to specify the actions necessary to take to effectively protect and carry out conservation of historic structures made in the technology of irregular masonry walls. These include the following conservation activities $[24,25]$ : 
- Macroscopic and laboratory examinations aimed at identification of the technique of rising masonry, including identification of masonry elements, bonding and their arrangement in the masonry, physical properties of mortar and masonry elements.

- Detailed geometrical survey of masonries, with their location in the plan, preparation of geometrical survey, drawing and photographic documentation. A specific form of measurement and preparation of drawing and photographic documentation is the digitalization of the excavation area using 3D laser scanning [23, 27].

- Preparation of the appropriate mortar for conservation and renovations.

- The reprofiling of existing masonry parts with the anastylosis or semianastylosis method, using prepared mortar; internal bonding of the wall, internal consolidation (Fig. 3). During reprofiling, all plants destroying the masonry structure should be effectively removed. The masonry reprofiling was realized in stages - rebuilding, bonding, consolidation with appropriate mortar, pointing - placing a pointing mortar to a fresh grout, joints complementation with pointing mortar after grout hardened and mechanical cleaning.
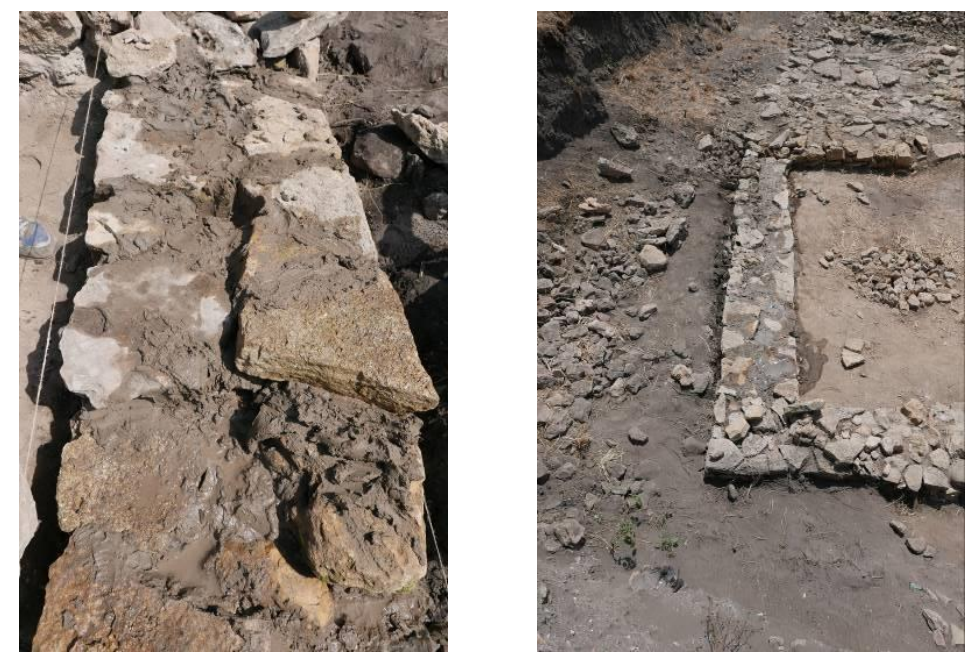

Fig. 3. Irregular masonry during conservation works: reprofiling and internal consolidation (on the left) and curing during conservation work (on the right).

For properly made reprofiling, in connection with possible superstructure (partial reconstruction) of the wall, the previously made documentation is necessary (photographic, drawing, numerical). The collected data will present the original arrangement of elements in the wall. The binding method and arrangement of wall elements in the reprofiled wall should be ensured, that reflects the original layout, preserving historical truth. The superstructured (reconstructed) layers should be visibly separated from the original ones (for example by placing a ceramic layer in the joint).

\section{Conclusions}

Conservation of ancient architectural monuments is an issue that requires broad knowledge and experience. The article presents assumptions that should be followed during conservation of irregular masonries based on the example of Tanais archaeological site. Given methodology is a result of authors' experience gained during many years of studies and experiments performed in the frames of conservation projects. It derives and it is fully consistent with international treats related to conservation of archaeological monuments. 
Appropriate conservation of the ancient structures, what is related to improvement of their durability and strengthening, is a rightful implementation of protection of cultural heritage. Moreover, proper exhibition of ancient architectural monuments has enormous educational value. Protection and preservation of monuments for further generation is the most precise application of the principles of sustainable development.

This paper is a result of implementation of a research project funded by the National Science Centre (Poland): 2016/21/B/HS3/03423

\section{References}

1. Strabo, Geography (1903)

2. D.B. Shelov, Nauka, (1970)

3. S.M. Il'yashenko, Vest. Tanais. 2, 27, (2007)

4. V. Kozlovskaya, and S.M. Ilyashenko, Explor. the Hosp. Sea. Proc. of the Internat.

Work. on the Black Sea in Antiq. in Thessaloniki, (Archaeopress, 2013)

5. G. Jöhrens, Antiq. 11, 98, (2005)

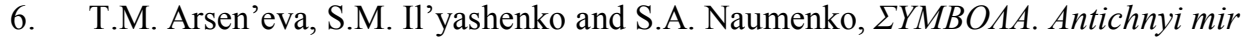
Severnogo Prichernomor'ya. Noveishyie nachodki i otkrytiya, vyp. I., 11-21 (2010)

7. T. Scholl, Eurasia Anti. 11, 137-145, (2005)

8. T. Scholl, Étud. et Trav. XX, 247-259, (2005)

9. T. Scholl, Noven. 18-19, 307-338, (2008)

10. T. Scholl, in Pontika 2006. Recent Research in Northern Black Sea Coast Greek Colonies. Proceedings of the International Conference, 177-189, (2008)

11. T. Scholl, Blisko i daleko. Księga Jub. Inst. Archeo. UW, 167-173, (2009)

12. T. Scholl, Archäo. der Brück. Vorge., Anti., Mittel., 58-60, (2011)

13. T. Scholl, in Pontika 2008. Recent Research on the Northern and Eastern Black Sea in Ancient Times. Proceedings of the International Conference, 299-303, (2011)

14. T. Scholl, Arkheol., drev. mir i sred. 5, 11-16, (2012)

15. T. Scholl and M. Matera, Bospo. Chten. 13, 482-488, (2012)

16. T. Scholl and A. Rovin'ska, Vest. Tana. 3, 48-62, (2013)

17. S. Naumenko and T. Scholl, in Tyritake. Antiq. site cimmerian bosporus. Proc. Int. Conf., 187-201, (2014)

18. T. Scholl, Stud. in Anc. Art and Civil. 17, 319-321, (2013)

19. T. Scholl, in Miasta bosporańskie od VI po połowy I wieku p.n.e., 199-206 and 210216, (2014)

20. M. Matera, New data about the western part of Tanais - the fortifications and their vicinity, (to be published)

21. M. Matera and T. Scholl, Hellenistic housing in Western Tanais, (to be published)

22. M. Matera, O osobennostyach zhiznii v zapadno Tanaise posle polemonovskogo razgroma, (to be published)

23. M. Gregoriou-Szczepaniak, W. Terlikowski, K. Wasilewski, E. Sobczyńska, P.

Bartosiak, in PROHITECH 3 rd Int. Conf. Prot. Hist. Constr., 249-250, (2017)

24. W. Terlikowski, K. Wasilewski, in Tyritake. Antiq. site cimmerian bosporus. Proc.

Int. Conf., 83-95, (2014)

25. W. Terlikowski, K. Wasilewski, in PROHITECH'14. Proc. 2nd Int. Conf. Prot. Hist. Constr., 759-766, ( 2014)

26. Eur. Treaty Ser. - No. 143, (1992)

27. M. Murphy, E. McGovern, S. Pavia, ISPRS J. Photogramm. Remote Sens., 76,89-

$102,(2013)$ 